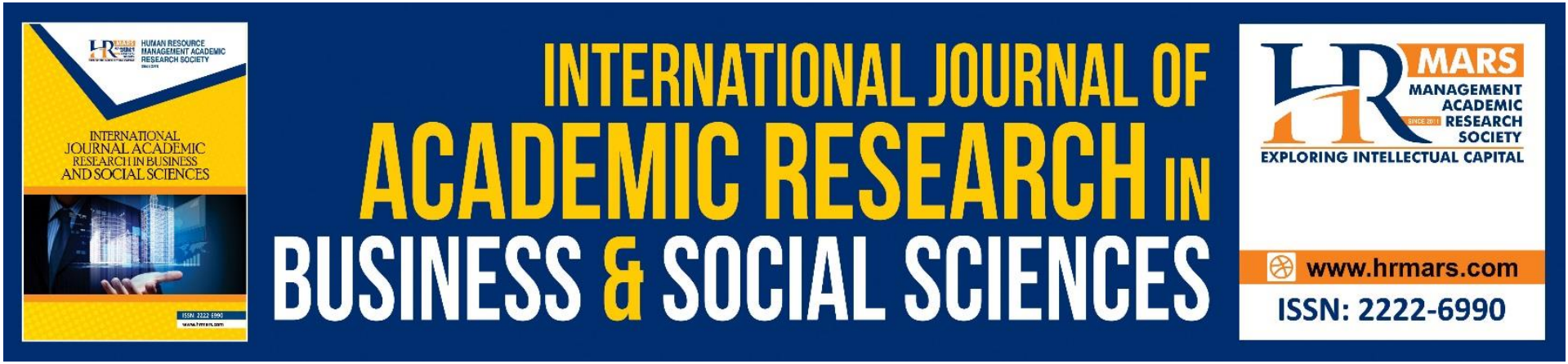

\title{
A Needs Study Toward Developing Ma-TVETTCM Instrument to Measure TVET Teacher Competencies
}

\section{Muhammad Aiman Arifin, Farah Lina Azizan, Athifah Najwani Shahidan}

To Link this Article: http://dx.doi.org/10.6007/IJARBSS/v11-i6/10104 DOI:10.6007/IJARBSS/v11-i6/10104

Received: 15 April 2021, Revised: 18 May 2021, Accepted: 15 May 2021

Published Online: 11 June 2021

In-Text Citation: (Arifin et al., 2021)

To Cite this Article: Arifin, M. A., Azizan, F. L., \& Shahidan, A. N. (2021). A Needs Study Toward Developing MaTVETTCM Instrument to Measure TVET Teacher Competencies. International Journal of Academic Research in Business and Social Sciences, 11(6), 152-158.

Copyright: (C) 2021 The Author(s)

Published by Human Resource Management Academic Research Society (www.hrmars.com)

This article is published under the Creative Commons Attribution (CC BY 4.0) license. Anyone may reproduce, distribute, translate and create derivative works of this article (for both commercial and non-commercial purposes), subject to full attribution to the original publication and authors. The full terms of this license may be seen

at: http://creativecommons.org/licences/by/4.0/legalcode

Vol. 11, No. 6, 2021, Pg. 152 - 158

http://hrmars.com/index.php/pages/detail/IJARBSS

JOURNAL HOMEPAGE

Full Terms \& Conditions of access and use can be found at http://hrmars.com/index.php/pages/detail/publication-ethics 


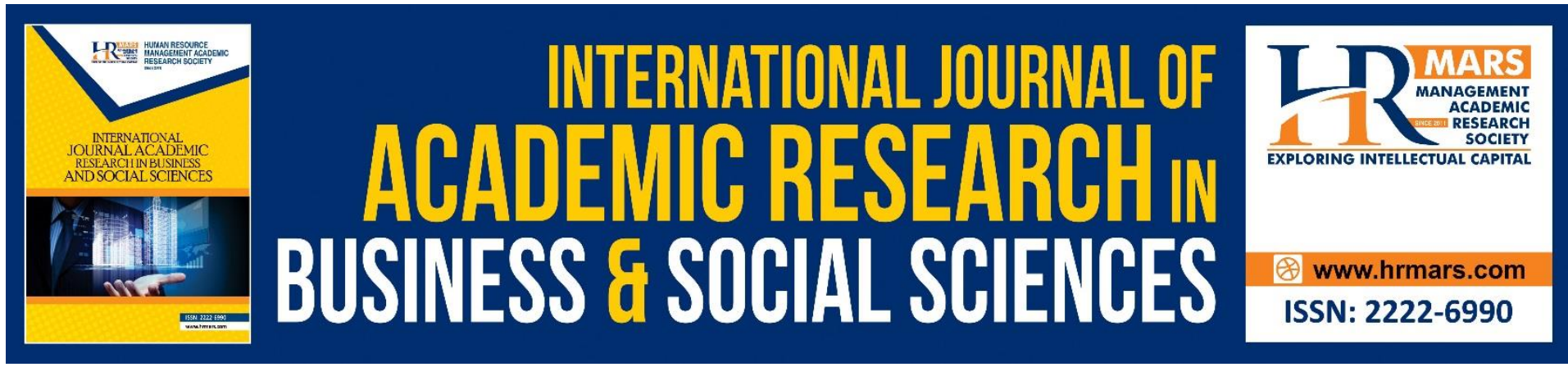

\title{
A Needs Study Toward Developing Ma-TVETTCM Instrument to Measure TVET Teacher Competencies
}

\section{Muhammad Aiman Arifin, Farah Lina Azizan, Athifah Najwani Shahidan}

Faculty of Business and Management, Universiti Teknologi Mara Cawangan Perlis, Kampus Arau, 02600 Arau, Perlis, Malaysia.

Email: aimanarifin@uitm.edu.my, farahlina@uitm.edu.my, athifahnajwani@uitm.edu.my

\begin{abstract}
Competency-based assessment (CBA), as one of the main functions in human resource, has attracted many researchers and practitioners including in the field of technical and vocational education and training (TVET). In today's world of work, the practice of competency-based assessment is necessary to enhance the future level of knowledge, skills, and abilities of an employee. Tools such as a competency measurement instrument that is valid and reliable to measure TVET teacher competencies should be developed. With few existing instruments identified through a systematic literature review procedure, a needs study has been conducted regarding the need for this instrument. This study employed a quantitative research method and data was collected through a survey where a questionnaire was the main instrument. The finding among 40 respondents revealed that $90 \%$ of respondents agreed with the need to develop an instrument to measure TVET teacher competencies. This paper presents the need findings to develop a new instrument to measure TVET teacher competencies namely the Ma-TVETTCM Instrument. This study also discusses a few suggestions for future studies toward understanding the competency elements required for TVET teachers.
\end{abstract}

Keywords: Need Analysis, Competency, Instrument Development, TVET Teacher, Human Resource

\section{Introduction}

Competency-based assessment as part of the tools for individual employee knowledge, skills, and abilities assessment has gained tremendous attention from many researchers across multiple disciplines including in Human Resource development (Howard et al., 2018; McCartney et al., 2020) as well as Technical and Vocational Education and Training (TVET) (Hager et al., 1994; Suhairom et al., 2014). In Malaysia, the government under the Ministry of Education has included competency as one of the main issues and challenges to be addressed (Economic Planning Unit, 2015). The ministry has also highlighted that future initiatives on the 
training and development of TVET teachers need to be conducted in order to enhance the level of competencies.

In the last few years, the concept of competence, competency, and competencies has attracted more interest. From TVET perspectives, there is a need to use competency practices to measure TVET teacher performance (Paryono, 2015). This practice has also been widely used in organizational settings for specific job positions to measure and justify an employee's current level of knowledge, skills, and abilities using the identified performance indicator. In selection and recruitment, with strong tools to measure employee performance, organizations are also able to select competent employees to be their staff. Thus, this kind of assessment tool not only must be valid (Cardy \& Selvarajan, 2006) but should also be reliable with strong psychometric properties to measure the employee. However, a systematic review has demonstrated a lack of evidence of an instrument to measure TVET teacher competencies.

A systematic literature review shows that although there are existing instruments that have been built either internally or externally, most of them have unfortunately been built around the teaching profession from a general perspective. Therefore, they concentrate more on classroom teaching, not least because teachers of general subjects usually outnumber teachers of vocational subjects (Soysouvanh et al., 2013). In contrast, the nature of vocational education involves more situations outside the classroom environment, either in workshop settings or in a real work environment (Soysouvanh et al., 2013). Thus, the knowledge to be imparted is not similar to the contents of general education, as the approach is not purely academic but instead places emphasis on the real world of work and industrial needs. Further, the teaching and learning modes are different for every course.

Therefore, there is a need for TVET teachers to understand the required competency elements specific to the profession. As mentioned by Huei et al. (2019 and Nornazira et al. (2015), a needs analysis must be conducted to support the need for the study, study feasibility, examine the problem, and to suggest possible solutions to address the problems. The purpose of this study is to discuss the need toward developing a new instrument to measure TVET teacher competencies as perceived by Malaysian TVET teachers.

\section{Methodology}

This study adopted a quantitative approach using a descriptive survey to achieve the objectives. In the course of attending several conferences, a set of questionnaire was prepared and randomly distributed among conference participants. The participants in the study come from various backgrounds especially academics, practitioners from the industry as well as TVET teachers from public institutions. There are 12 items in the questionnaire that measure the need for developing a new instrument for competency measurement. The researcher adapted the instrument using the study by (Nornazira et al., 2015) which focused on the development of a competency model and instrument for measuring chef competencies. The sample used in the study is 40 TVET experts, who are directly involved in TVET teaching and learning. The questionnaire consists of two sections. Section A focuses on the respondents' background (demographic information) while section $B$ contains close-ended questions that identify the need for the development of a new instrument to measure TVET teacher competencies. 


\section{Results and Discussion}

Findings from the study are discussed in three sections: (1) respondent's demographic information, (2) classification of the respondent based on job position, (3) institutions as well as their level of perception toward developing the instrument for competency measurement comprising 12 items with 40 respondents.

\section{Survey Findings}

Overall, the instrument consists of 12 items reflecting the needs of a competency measurement instrument with the reliability value of Cronbach's alpha at 0.85 . In this preliminary study, only 40 completed questionnaires returned by the respondents were selected for further analysis. The first section describes the respondent's characteristics (gender, age, experience, and institution) as in Table 1 below.

Table 1: Summary of the Study Respondents' Demographic Information

\begin{tabular}{|l|l|c|c|}
\hline Demographic & \multicolumn{1}{|c|}{ Characteristics } & Frequency (f) & Percent (\%) \\
\hline \multirow{3}{*}{ Gender } & Male & 22 & 55.0 \\
\cline { 2 - 4 } & Female & 18 & 45.0 \\
\hline \multirow{5}{*}{ Age } & $31-40$ years old & 4 & 10.0 \\
\cline { 2 - 4 } & $41-50$ years old & 21 & 52.5 \\
\cline { 2 - 4 } & Over 50 years old & 15 & 37.5 \\
\hline \multirow{5}{*}{ Experience } & 5-10 years & 15 & 37.5 \\
\cline { 2 - 4 } & $11-15$ years & 22 & 55.0 \\
\cline { 2 - 4 } & Over 15 years & 3 & 7.5 \\
\hline & University (Academics) & 20 & 50.0 \\
\cline { 2 - 4 } & TVET Institutions & 10 & 25.0 \\
\cline { 2 - 4 } & Industry & 10 & 25.0 \\
\hline
\end{tabular}

Note: $n=40$

Based on the individual backgrounds, the respondents who participated are further classified as either from universities, TVET institutions, or industry. The following Table 2 and Table 3 summarize the classification of the study respondents representing the population of TVET experts in Malaysia

Table 2: Classification of the Respondents According to Institution

\begin{tabular}{|l|l|c|c|c|}
\hline \multicolumn{1}{|c|}{ Sectors } & \multicolumn{1}{|c|}{ Criteria } & f & $\%$ & Total \% \\
\hline \multirow{2}{*}{ 1. Education } & University & 20 & 50.0 & 75.0 \\
\cline { 2 - 4 } & TVET Institution & 10 & 25.0 & \\
\hline \multirow{2}{*}{ 2. Industry } & Industry & 10 & 25.0 & 25.0 \\
\hline
\end{tabular}

\section{Perceptions toward Instrument for Competency Measurement}

As shown in Table 3, the findings of the survey conducted by the researchers revealed that most of the respondents have a positive agreement toward the need for the development of a new instrument to measure TVET teacher competencies. Table 3: Perception toward the Need for the Development of a Measurement Instrument to Measure TVET Teacher Competencies 


\begin{tabular}{|c|c|c|c|c|c|c|c|}
\hline Statement & SD & $D$ & SWA & $A$ & SA & $M$ & Sd \\
\hline $\begin{array}{l}\text { Currently, there is no comprehensive framework for } \\
\text { TVET teacher competency modeling }\end{array}$ & $\begin{array}{l}0 \\
0\end{array}$ & $\begin{array}{l}0 \\
0\end{array}$ & $\begin{array}{l}7 \\
17.5\end{array}$ & $\begin{array}{l}8 \\
20.0\end{array}$ & $\begin{array}{l}25 \\
62.5\end{array}$ & 4.45 & 0.783 \\
\hline $\begin{array}{l}\text { There is a need to develop a framework for TVET } \\
\text { teacher competency modeling }\end{array}$ & 0 & 0 & $\begin{array}{l}5 \\
12.5\end{array}$ & \begin{tabular}{l|l}
9 \\
22.5
\end{tabular} & $\begin{array}{l}26 \\
65.0\end{array}$ & 4.53 & 0.716 \\
\hline $\begin{array}{l}\text { Currently, there is no comprehensive instrument for } \\
\text { measuring TVET teachers' competencies in Malaysia }\end{array}$ & 0 & 0 & $\begin{array}{l}4 \\
10.0\end{array}$ & $\begin{array}{l}20 \\
50.0\end{array}$ & $\begin{array}{l}16 \\
40.0 \\
\end{array}$ & 4.30 & 0.649 \\
\hline $\begin{array}{l}\text { Having an instrument for measuring TVET teachers' } \\
\text { competencies will help TVET teachers to identify } \\
\text { competencies in terms of individual job performance } \\
\text { in the teaching profession }\end{array}$ & $\begin{array}{l}0 \\
0\end{array}$ & $\begin{array}{l}0 \\
0\end{array}$ & $\begin{array}{l}10 \\
25.0\end{array}$ & \begin{tabular}{l|}
28 \\
70.0
\end{tabular} & $\begin{array}{l}2 \\
5.0\end{array}$ & 3.80 & 0.516 \\
\hline $\begin{array}{l}\text { Having an instrument for measuring TVET teachers' } \\
\text { competencies will guide TVET teachers toward } \\
\text { effective job performance in the teaching profession }\end{array}$ & $\begin{array}{l}0 \\
0\end{array}$ & $\begin{array}{l}0 \\
0\end{array}$ & $\begin{array}{l}8 \\
20.0\end{array}$ & \begin{tabular}{l|}
26 \\
65.0
\end{tabular} & $\begin{array}{l}6 \\
15.0\end{array}$ & 3.95 & 0.597 \\
\hline $\begin{array}{l}\text { Having an instrument for measuring TVET teachers' } \\
\text { competencies will help teachers to be aware of their } \\
\text { essential competencies in order to fulfill the new } \\
\text { requirements of the TVET teaching profession }\end{array}$ & $\begin{array}{l}0 \\
0\end{array}$ & $\begin{array}{l}0 \\
0\end{array}$ & $\begin{array}{l}7 \\
17.5\end{array}$ & \begin{tabular}{l|}
29 \\
72.5
\end{tabular} & $\begin{array}{l}4 \\
10.0\end{array}$ & 3.93 & 0.526 \\
\hline $\begin{array}{l}\text { An instrument for measuring TVET teachers' } \\
\text { competencies is important for TVET teachers' self- } \\
\text { assessment }\end{array}$ & $\begin{array}{l}0 \\
0\end{array}$ & $\begin{array}{l}0 \\
0\end{array}$ & $\begin{array}{l}7 \\
17.5\end{array}$ & $\begin{array}{l}28 \\
70.0\end{array}$ & $\begin{array}{l}5 \\
12.5\end{array}$ & 3.95 & 0.552 \\
\hline $\begin{array}{l}\text { Having an instrument for measuring TVET teachers' } \\
\text { competencies will help vocational education } \\
\text { institutions to produce skilled TVET students to meet } \\
\text { industry demands }\end{array}$ & $\begin{array}{l}0 \\
0\end{array}$ & $\begin{array}{l}0 \\
0\end{array}$ & $\begin{array}{l}0 \\
0\end{array}$ & $\begin{array}{l}32 \\
80.0\end{array}$ & $\begin{array}{l}8 \\
20.0\end{array}$ & 4.20 & 0.405 \\
\hline $\begin{array}{l}\text { Having an instrument for measuring TVET teachers' } \\
\text { competencies will help training and education } \\
\text { institutions to identify which areas in the curriculum } \\
\text { need to be developed or improved to be able to } \\
\text { meet industry demands. }\end{array}$ & $\begin{array}{l}0 \\
0\end{array}$ & $\begin{array}{l}0 \\
0\end{array}$ & $\begin{array}{l}1 \\
2.5\end{array}$ & $\begin{array}{l}27.0 \\
67.5\end{array}$ & $\begin{array}{l}12.0 \\
30.0\end{array}$ & 4.28 & 0.506 \\
\hline $\begin{array}{l}\text { Having an instrument for measuring TVET teachers' } \\
\text { competencies will help the human resource } \\
\text { department in shaping the initial and in-service } \\
\text { vocational teacher education and training especially } \\
\text { in professional courses in order to support their } \\
\text { career development }\end{array}$ & $\begin{array}{l}0 \\
0\end{array}$ & $\begin{array}{l}0 \\
0\end{array}$ & $\begin{array}{l}1 \\
2.5\end{array}$ & $\begin{array}{l}28 \\
70.0\end{array}$ & $\begin{array}{l}11 \\
27.5\end{array}$ & 4.25 & 0.494 \\
\hline $\begin{array}{l}\text { Both job and personal competencies are necessary } \\
\text { for TVET teachers to become competent teachers }\end{array}$ & $\begin{array}{l}0 \\
0\end{array}$ & $\begin{array}{l}0 \\
0\end{array}$ & $\begin{array}{l}0 \\
0\end{array}$ & \begin{tabular}{l|l|}
6 \\
15.0 \\
\end{tabular} & \begin{tabular}{l|l}
34 \\
85.0 \\
\end{tabular} & 4.85 & 0.361 \\
\hline $\begin{array}{l}\text { Having a comprehensive instrument comprising } \\
\text { teaching, professional, communication, and personal } \\
\text { competencies is vital for the current TVET teaching } \\
\text { profession. }\end{array}$ & $\begin{array}{l}0 \\
0\end{array}$ & $\begin{array}{l}0 \\
0\end{array}$ & $\begin{array}{l}0 \\
0\end{array}$ & \begin{tabular}{l|l|}
6 \\
15.0
\end{tabular} & $\begin{array}{l}34 \\
85.0\end{array}$ & 4.85 & 0.361 \\
\hline \multicolumn{6}{|l|}{ Total } & 4.28 & 0.485 \\
\hline
\end{tabular}

$S A=$ Strongly Agree, $A=$ Agree,$S M A=$ Somewhat Agree, $D=$ Disagree, $S D=$ Strongly Disagree

$M=$ Mean,$S d=$ Standard Deviation

Note: $n=40$ 
Table 3 summarizes the distribution of the importance level based on the survey responses. A majority of the expert panel (90.0\%) agreed that there are currently no comprehensive instruments for measuring TVET teacher competencies. The expert panel was also asked the significance of having the new instrument, which can be a tool to ensure that all TVET teachers understand the importance of both job and personal competencies to be more effective in a profession and to produce skilled graduates to meet the demand from industry. From all of these items, more that $80 \%$ agreed to support the development of a new instrument to measure TVET teacher competencies. All of them (100\%) agreed that having an instrument for measuring TVET teacher competencies is important for TVET teacher self-assessment.

\section{Conclusion}

In line with the current issues and challenges that need to addressed, the knowledge, skill, and abilities of TVET teachers need to be enhanced for them to carry out their work competently. Hence, the development of an instrument to measure TVET teacher competencies is significant. Previous studies have proven the need for TVET teachers to possess teaching, professional, communication, and personal competencies in teaching and learning. The overall results of this study can explain the current level of competencies among TVET teachers. The outcome of the developed instrument can further be used to develop a competency profile specific to TVET teachers. The profile is expected to guide ministries and developing bodies to tailor specific training and development programs in the future.

\section{Future Study Perspectives}

Although this study is considered as a preliminary study to address this issue, it contributes to our understanding regarding the need to develop a new and comprehensive instrument to address TVET teacher competencies. As this study involved a small sample, future studies can be conducted across different job levels to understand more about TVET teacher competencies. A comparative study between two countries, for instance between eastern and western countries, would provide an insightful understanding regarding the competency elements, which are deemed necessary to perform in a profession.

\section{Acknowledgements}

The researchers are grateful for support provided by the Ministry of Education, Malaysia in the form of permission for data collection and TVET expert panel to participate in this study.

\section{Corresponding Author}

Farah Lina Azizan

Faculty of Business and Management, Universiti Teknologi Mara Cawangan Perlis, Kampus Arau, 02600 Arau, Perlis, Malaysia.

Email: farahlina@uitm.edu.my

\section{References}

Cardy, R. L., \& Selvarajan, T. T. (2006). Competencies: Alternative frameworks for competitive advantage. Business Horizons, 49(3), 235-245.

Economic Planning Unit. (2015). 11 Malaysia Plan. In Rancangan Malaysia Kesebelas (Eleventh Malaysia Plan) : 2016-2020.

Hager, P., Gonczi, A., \& Athanasou, J. (1994). General Issues about Assessment of Competence. Assessment \& Evaluation in Higher Education, 19(1), 3-16. 
Howard, P. F., Liang, Z., Leggat, S., \& Karimi, L. (2018). Validation of a management competency assessment tool for health service managers. Journal of Health Organization and Management.

Huei, O. K., Rus, R. C., \& Kamis, A. (2019). Need Analysis: Competency Development Measurement Instrument in Mastering the Content of Design and Technology Subject in High School. International Journal of Academic Research in Business and Social Sciences.

McCartney, S., Murphy, C., \& Mccarthy, J. (2020). 21st century HR: a competency model for the emerging role of HR Analysts. Personnel Review. https://doi.org/10.1108/PR-122019-0670

Nornazira, S., Aede H. M., Nor, F. M. A., \& Noor, K. A. J. (2015). A preliminary study of the needs for the development of competency measurement instrument for Malaysian chefs. Pertanika Journal of Social Sciences and Humanities, 23(August), 159-172.

Paryono, P. (2015). Approaches to preparing TVET teachers and instructors in ASEAN member countries.TVET@Asia, 5, 1-27.

Soysouvanh, B., Khammounty, B., Virivong, S., Phoumvilay, P., Elsholz, U., \& Bohlmann, T. (2013). Developing standards of vocational teacher at bachelor level in Lao PDR. TVET@Asia, 2, 1-19.

Suhairom, N., Musta'amal, A. H., Amin, N. F. M., \& Johari, N. K. A. (2014). The Development of Competency Model and Instrument for Competency Measurement: The Research Methods. Procedia - Social and Behavioral Sciences, 152, 1300-1308. 